\section{History and Current Trends in the Use of Allelopathy for Weed Management}

\author{
Leslie A. Weston
}

AdDitional InDEX words. allelopathy, weed management, plant interference, secondary products, soil rhizosphere, herbicides, root exudation, decomposition, plant residue, environment, breeding, weed suppressive crops

Summary. Allelopathy can be defined as an important mechanism of plant interference mediated by the addition of plant-produced secondary products to the soil rhizosphere. Allelochemicals are present in all types of plants and tissues and are released into the soil rhizosphere by a variety of mechanisms, including decomposition of residues, volatilization and root exudation. Allelochemical structures and modes of action are diverse, and may offer potential for development of future herbicides. In the past, allelopathy was described by the Romans as a process resulting in the "sickening" of the soil; in particular, chickpea (Cicer arietinum) was described as problematic when successively cropped with other species. Other early plant scientists, such as De Candolle in the 1800s, first described the ability of plant roots to produce toxic exudates. More recently, research has focused on development of weed management strategies using allelopathic crop residues, mechanism of allelochemical action, and gene regulation of allelochemical production. This paper briefly describes a variety of weed and crop species that establishes some form of potent allelopathic interference, either with other crops or weeds, in agricultural settings, in the managed landscape, or in naturalized settings. Recent research suggests that allelopathic properties can render one species more invasive to native species and thus potentially detrimental to both agricultural and naturalized settings. In contrast, allelopathic crops offer strong potential for the development of cultivars that are more highly weed suppressive in managed settings. A new challenge

Department of Horticulture, Cornell University, Ithaca, NY 14853.

E-mail address: law20@cornell.edu that exists for plant scientists is to generate additional information on allelochemical mechanisms of release, selectivity and persistence, mode of action, and genetic regulation. Armed with this specific information, we can further protect plant biodiversity and enhance weed management strategies in a variety of ecosystems.

$\mathrm{T}$ he term allelopathy was first introduced by Molisch in 1937 and refers to chemical interactions among plants, including those mediated by microorganisms. This definition, although broad, is reasonable, as considerable research has recently indicated the involvement of microorganisms and lower plants in the production of phytochemically active compounds (Inderiit and Weiner, 2001; Putnam, 1986; Rice, 1984). Allelopathy may be further defined as an important mechanism of plant interference mediated by the addition of plant-produced secondary products to the rhizosphere. Chemicals with allelopathic potential are present in nearly all plants and their respective tissues, including leaves, stems, roots, flowers, seeds, bark, and buds. Under the appropriate environmental conditions, these phytotoxins may be released into the environment in sufficient quantities to affect the growth of neighboring plants (Weston, 1996).

Allelopathic interference mechanisms are particularly difficult, if not impossible, to separate from interference due to competition under field conditions. Plant interference can be defined as any physical or chemical mechanism that results in reduction of plant growth over time due to the presence of another plant. Competition is usually described as the process whereby plants interfere with the growth of neighboring plants by utilization or competition for growthlimiting resources, including space, light, nutrients, or moisture. Both competition and allelopathy as mechanisms of plant interference have been well documented under controlled conditions. The appropriate design of laboratory bioassays to assess allelopathic activity will continue to aid in the development of our understanding of the mechanisms underlying growth inhibition and modes of action of novel allelochemicals (Inderjit and Weston, 2000). 


\section{Historical perspectives on allelopathy}

For over 2000 years, allelopathy has been reported in the literature with respect to plant interference. Ancient literature has described the growth of crops that "rob the soil of nutrients," "sicken the soil," and even referred to roots producing toxins that suppress plant growth. The earliest recorded observations of weed and crop allelopathy were made by none other than Theophrastus (300 BC) and Pliny II ( 1 AD). Pliny reported that chickpea, barley (Hordeum vulgare), fenugreek (Trigonella foenum-graecum), and bitter vetch (Vicia ervilia) destroy or burn up farmland (Rice, 1984). He also described the shade of black walnut (Juglans spp.) as heavy and believed that walnut and its residues could cause potential injury to man and anything planted in the vicinity (Fig. 1). Pliny was apparently aware that release of chemicals by plants contributed to this soil sickness, as evidenced by his statement: "The nature of some plants though not actually deadly is injurious owing to its blend of scents or of juice...."

In the 1600s several naturalists noted in the English literature that certain plants do not grow well in the presence of each other. The Japanese literature also shows examples of plants causing injury to others due to the production of extracts of toxic compounds with rainfall, specifically japanese red pine (Pinus densiflora) (Rice, 1984). In the 1800s, agronomists started to note problems with repeated cropping of certain perennials. For example, in 1804 , Young discovered that clover was apt to fail in some regions of England where it is cultivated constantly due to soil sickness that accrues over time. De Candolle was one of the first to actually perform experiments examining the toxicity associated with root exudates (de Candolle, 1832; Singh et al., 2001). In 1881, Stickney and Hoy observed that vegetation under black walnut was very sparse in pasture settings, and pointed out that this might be due to high mineral requirement of the tree, or the poisonous character of the moisture dripping off the tree itself. As Rice indicates, if one peruses older literature, there are many examples described by botanists, farmers, and gardeners that strongly suggest allelopathic interactions among plants. It is interesting to note that many of the species demonstrated to have powerful medicinal effects on humans also have been subsequently demonstrated to have powerful allelopathic effects as well (Chevallier, 1996; Rice, 1984; Wink, 1999).

Interest in the field of allelopathy revived again in the 20th century, with the development of suitable techniques for extraction, bioassay, and chemical isolation and structural elucidation (Willis, 1997). During the period from 1960 to 1990 , great advances were made in the fields of liquid-column and high-pressure liquid-column chromatography for separation, and nuclear magnetic resonance spectroscopy and mass spectrometry for structural elucidation of unknown natural products. McCalla et al. published a series of papers from 1948 until 1965 that described allelochemicals produced from plant residues and the importance of the interaction of microbes upon the decomposition of these residues (Putnam and Weston, 1986). Two outstanding contributors to the field of allelopathy during this period also included Muller and his associates at Santa Barbara, Calif., who published many articles on volatile inhibitors produced by plants growing in the chaparral and desert. Rice at the University of Oklahoma contributed many papers to the field and described impacts of allelochemicals on nitrifying and nitrogen-fixing bacteria in the soil rhizosphere, as well as classical works documenting allelopathy in prairie-type ecosystems of the central U.S. (Bell and Muller, 1973; Muller, 1969; Putnam and Weston, 1986; Rice, 1984). Rick Willis is now finishing an exhaustive review that thoroughly documents the history and the science of allelopathy as a field of research. Some of his work has recently been published in the Allelopathy Journal (Willis, 1997, 2000). In the past 5 years, the number of publications in the field of allelopathy has increased exponentially as physiologists, soil scientists, weed scientists, and natural

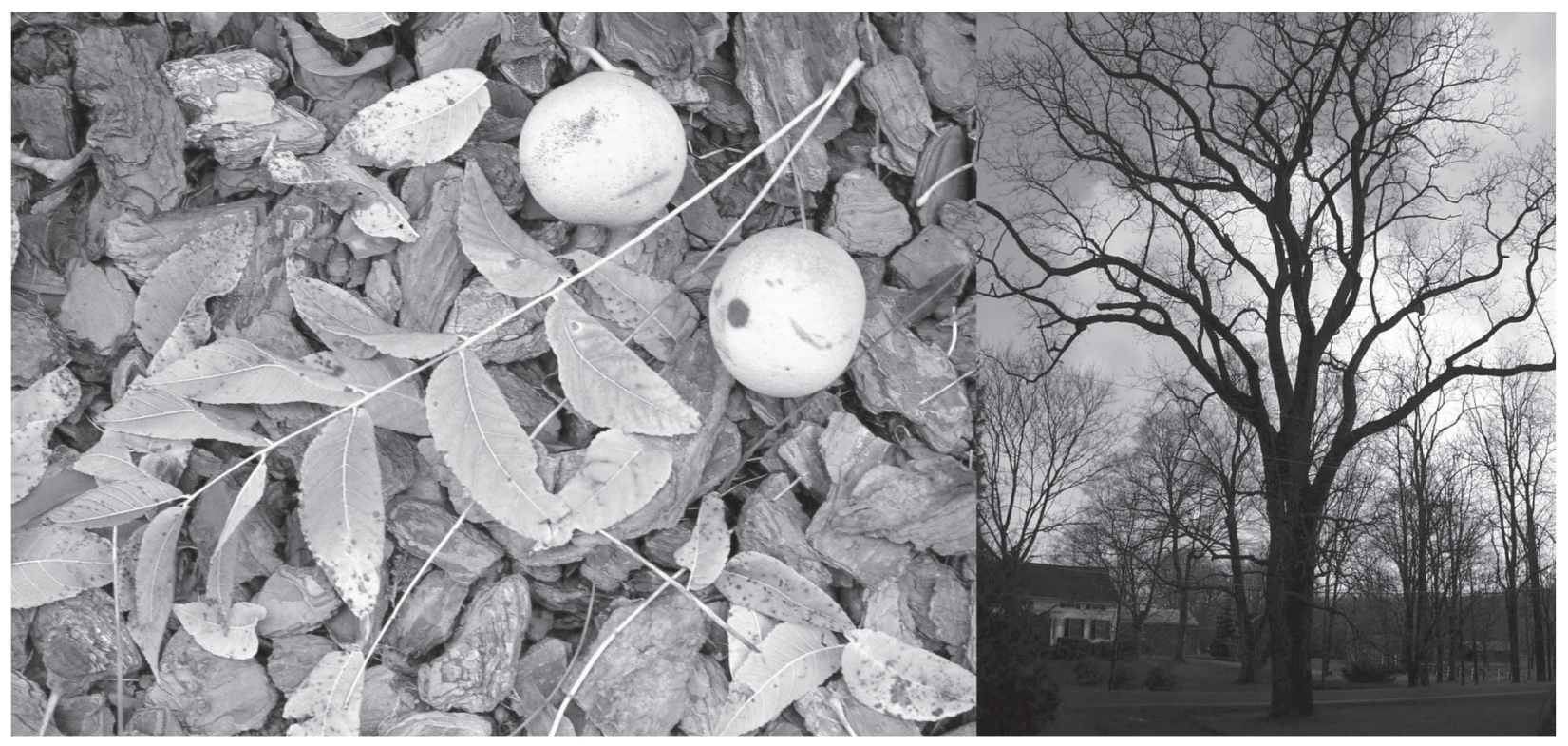

Fig. 1. Black walnut (Juglans nigra) foliage and fruit (left), mature tree (right). Black walnut often is cited as one of the most allelopathic of all perennial plant species in North America. 
product chemists continue to study this challenging area (Macias, 2002).

\section{Recent perspectives on allelopathy as means of weed suppression}

During the past 30 years, the potential impacts of allelopathy on agriculture have been described and discussed in detail (Putnam, 1986; Putnam and Duke, 1974, 1978; Putnam and Weston, 1986; Qasem and Foy, 2001; Rice, 1984; Singh et al., 2001; Weston, 1996). Putnam and Duke (1974) first explored the possibility of utilizing allelopathic crops to suppress weed growth in agricultural sites, including the development of weed-suppressive crops, and later described rotational crops, intercrops, or cover crops for effective weed suppression (Putnam and Duke, 1978). Recently, many investigations into the use of cover crops and their residues for weed suppression have been published: some with positive results leading to enhanced weed suppression and reduced herbicide inputs, and others with mixed results, showing yield reductions in crops following a weed suppressive cover (Barnes and Putnam, 1983, 1987; Burgos et al., 1999; Einhellig and Rasmussen, 1989; Masiunas et al., 1995; Moyer et al., 2000; Mwaja et al., 1995; Petersen et al., 2001; Sene et al., 2001; Shilling et al., 1985; Weston, 1996; Weston et al., 1989). In particular, the cultivar and species employed, the amount of biomass generated, field conditions at the time of establishment of the cash crop, soil type, and location all impact the ability of the cover crop residue to suppress weeds over time. Although the physical presence of the cover crop residue on the soil surface contributes to a weed-suppressive "mulch" effect, the chemical effect of phytotoxins released from decomposing residues also impacts weed control selectively (Burgos and Talbert, 2000; Nagabushana et al., 2001; Putnam, 1988; Weston, 1996). Certain weeds, particularly small-seeded annuals, have a tendency to be more highly suppressed in limited tillage systems with decomposing cover crop residues. Many small-seeded annual species are sensitive to the presence of simple and complex phenolics released over time from these residues (Blum, 1998; Blum and Shafer, 1988). This sensitivity may be selective, depending upon the phytochemicals released. As we learn more about which cultivars to utilize as cover crops or green manures, and consider time and density of planting, we can more effectively and selectively manage weeds early in the subsequent growing season, following establishment of the cash crop. Transplanting vegetable crops into killed residues has been one way in which use of cover crop residues can work successfully. Another technique is to utilize a living, low-growing suppressive mulch on the soil surface to prevent erosion and suppress weeds effectively in orchards, vineyards, and other perennial crops. Fine leaf fescues, and mixtures of forbs and grasses often are selected in these settings for their ability to suppress weeds and their low maintenance requirements (Fig. 2). They are also often stress tolerant as well (Bertin et al., 2003; Weston, 1990 ).

Allelopathic interactions in soil environments depend greatly on the turnover rate of allelochemicals in the soil rhizosphere and their interaction with clay, organic matter, and other factors that change the physicochemical and biotic characteristics of the soil (Blum, 1995; Blum and Shafer, 1988). Recent research by Blum and his laboratory associates have shown that soil texture, soil $\mathrm{pH}$, organic carbon, and available nitrogen are important in influencing uptake and of allelochemicals and their ability to persist in the presence of soil microorganisms (Blum, 1995; Blum, 1988). Soil moisture dynamics can also influence the phytotoxicity of allelochemicals. In recent studies by Blum, data suggested that enhanced evapotranspiration and lower soil mois- ture will also result in decreased plant phytotoxicity of allelochemicals in the soil solution (Blum, 2002).

Unfortunately, traditional breeding methods have not generally been employed to produce highly allelopathic crops with good yield potential (Duke et al., 2002). Recent discussion of the use of genetic engineering to enhance allelopathic traits indicates that this is not a simple task due to the multigenic nature of allelochemical biosynthesis. Nonetheless, the benefits in monetary and time-savings by reductions in hand labor or herbicide application could be extensive if incorporation of enhanced allelopathic or weed suppressive ability was successful in major agronomic crops (Duke et al., 2001, 2002; Scheffler et al., 2001). Genes involved in production of allelochemicals are now being elucidated (Scheffler et al., 2001; Yang et al., 2004) using a variety of molecular techniques.

Past research was conducted to evaluate weed suppression provided by various cultivars of cucumbers ( $\mathrm{Cucu}$ mis spp.) (Putnam and Duke, 1974), winter rye (Secale cereale) (Barnes and Putnam, 1987; Burgos et al., 1999); sorghum (Sorghum spp.) (Czarnota, 2001; Einhellig and Rasmussen, 1989; Nimbal et al., 1996a; Weston et al., 1989), winter wheat (Triticum aestivum), barley (Hordeum vulgare), sunflower (Helianthus annua) (Bertholdsson, 2004; Rice, 1984; Singh et al., 2001; Weston, 1996), fine fescues (Festuca spp.) (Bertin et al., 2003, Weston, 1990), rice (Oryza sativa) (Chou and Lin, 1976; Dilday et al., 1991; Kato-Noguchi et al., 2002;

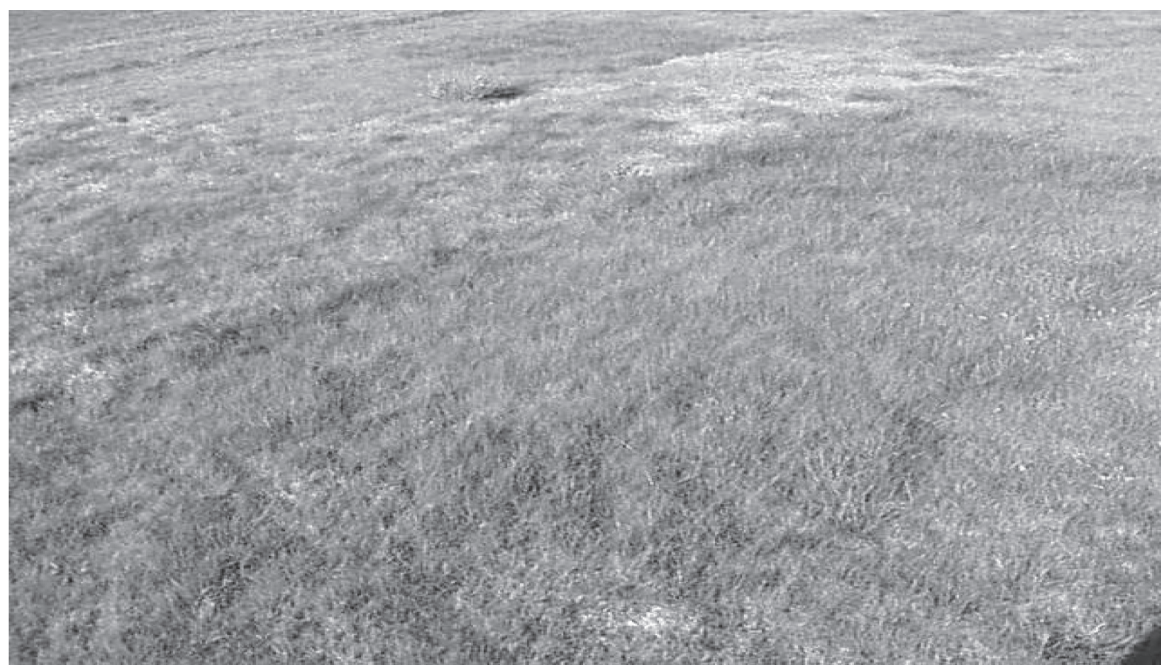

Fig. 2. An example of a weed-suppressive, allelopathic 'Intrigue' fine fescue (Festuca rubra). 
Mattice et al., 1998; Olofsdotter et al., 2002; Rimando and Duke, 2003), mustards (Brassica spp.) (Bell and Muller, 1973; Petersen et al., 2001; Siemens et al., 2002), and ornamental groundcovers (Nepeta spp.) (L.A. Weston, unpublished data). In recent research reported by Bertholdsson (2004), early vigor and allelopathic characteristics were often associated with older land races of barley and wheat that are now under evaluation again for development of organicallyproduced cereal grains. His studies have shown that weed suppressive characteristics are less often associated with newly developed cereal cultivars associated with high yield potential. Older cultivars that establish quickly and have these allelopathic characteristics can suppress weeds effectively over the course of the growing season, which is an important trait when one produces cereals organically (Bertholdsson, 2004). A reexamination of older germplasm may actually assist today's breeders in developing crops that are inherently more weed suppressive, as the tendency towards reduced herbicide usage continues.

The majority of past allelopathic research has focused upon the detrimental effects of living plants or their residues on plant growth and crop yields. Replanting problems associated with toxicity of mulch stubble, autotoxicity of perennial crops, crop rotations and direct interference by certain plants or weeds have all been attributed to allelochemicals (Putnam and Weston, 1986; Weston, 1996). Examples of allelopathic interactions cited in the literature include the cases of black walnut, alfalfa, asparagus, sorghum and mustard (Nimbal et al., 1996b; Putnam and Weston, 1986; Rice, 1984; Weston and Duke, 2003; Willis, 2000). Many of these decomposing plant residues exhibit selectivity in interference with plant growth, and environmental conditions strongly influence the activity of residues and compounds released. As a perennial crop remains in one location for an extended period of time, resulting suppression can increase over time. This is another research area that is continuing to receive attention and although complex, recommendations for rotational cropping systems and intercrops that result in reduced crop depression over time have been developed (Putnam and Weston, 1986; Weston and Duke, 2003).
Recent research suggests that allelopathic properties can render one species more invasive to native species and thus potentially detrimental to both agricultural and naturalized settings (Bais et al., 2003a, 2003b; Callaway and Aschehoug, 2002; Kilronomos, 2002; Ridenour and Callaway, 2001). Invasive plant species threaten the balance among natural systems throughout the world by displacing native plant communities and establishing monocultures. One leading theory regarding the success of invading species is that the absence of natural enemies allows them to use all of their resources for competition. A recent theory that is now being substantiated by published findings is that allelopathy may be associated with the success of some invasive plants (Inderjit and Weston, 2003; Weston and Duke, 2003). For example, Centaurea spp. (knapweeds) are among the most economically destructive invaders in North America (Fortuna et al., 2002; Muir and Majak, 1983). Recent findings from the laboratories of Vivanco and Callaway have shown that phytotoxic root exudates from spotted knapweed (C. maculosa), contain both + and - catechin which exhibit microbial and phytotoxic properties, respectively (Bais et al., 2002, 2003b). Natural catechin levels in soils from spotted knapweed in North America were more than twice as high as those soils collected from spotted knapweed-infested sites in Europe. The presence of the allelochemical apparently triggers the production of a wave of reactive oxygen species which leads to changes in gene expression and ultimate death of the root system of surrounding weed species (Bais et al., 2003b). Other invasive plants, including mugwort (Artemisia vulgaris), a noxious weed of nursery crops and roadsides in the northeastern and north-central U.S., may also influence surrounding plants through the production of secondary products (Barney and DiTommasso, 2003). Mugwort produces a mixture of phytotoxic volatiles, chemical members of the terpenoid family, which can successfully inhibit plant growth near the emitting foliage (Barney et al., 2005 ). Another example of a noxious invasive species producing an interesting mixture of potential inhibitors is that of japanese knotweed (Polygonum cuspidatum) (Beerling et al., 1994). This particular species establishes in large monocultures along roadsides across both northeastern and northwestern U.S. and throughout Great Britain. It reproduces by a vast network of rhizomes, pieces of which can be transported along streambeds and waterways. The roots of this species also produce a complex combination of antibacterial, antifungal and phytotoxic compounds (Kimura et al., 1983), including resveratrol, piceid, anthroquinones and their glucosides, as well as + catechin and a methyljuglone, both reported as potent allelochemics causing plant growth inhibition and death (Bais et al., 2003; Willis, 1997). Further work on japanese knotweed is currently occurring in our laboratory, which is interested in investigating genotypic diversity among knotweed introductions and allelochemicals produced by this aggressive invader. A third example is that of garlic mustard (Alliara petiolata), a noxious weed invading understory areas in North America. This particular mustard produces a number of isothiocyanates that inhibit seed germination and plant growth and likely contribute to the establishment of dense monocultures in these understory sites of infestation (Vaughn and Berhow, 1999).

The diversity of secondary products produced by plants is vast and chemicals range in structure from simple hydrocarbons to complex polycyclic aromatics. Nearly every class of secondary products or metabolites has been implicated in allelopathic interference (Rice, 1984; Putnam, 1988, Quasem and Foy, 2001). Much time and effort has been spent on identifying novel secondary products isolated from higher plants, as phytochemicals with biological activity have had great utility as pharmaceuticals and pest-management products (Duke, 1986; Duke et al., 2002). However, considering the large number of plant-derived products, we have probably discovered very few of their potential uses in agriculture and medicine (Duke et al., 2000). Certain allelochemicals may also possess novel modes of action, and interest exists in utilizing them as herbicide templates, especially for those natural products which act as inhibitors of plant specific processes, such as photosynthesis or chlorophyll synthesis (Duke, 1986; Gonzalez et al., 1997; Hejl et al., 1993; Nimbal et al., 1996b). Furthermore, as the rhizosphere and plant root ecology remain as 
areas that are relatively understudied in terms of allelopathic interactions, more attention to the novel allelochemicals contained in root exudates and their interactions with soil microorganisms, weed propagules, and macrobiota would be helpful in advancing our understanding of plant interactions. Recent articles published by Calloway and Aschehoug, Kilronomos, and Inderjit and Weston, as well as several symposia presented at the 2003 meetings of the Ecological Society of America, have suggested an important role of root exudates in the soil rhizosphere. Root exudates may have dramatic impacts on soil rhizosphere ecology, including enhancement of certain soil microbial populations and dramatic reductions in others, leading to a shift in nutrient availability and uptake by plants within the ecosystem (Kilronomos, 2002; Inderjit and Weston, 2003; Nair et al., 1990).

Given the large and ever-increasing body of literature surrounding the field of allelopathy and weed and crop interference, I have tried to present an overview of the history and recent developments in the field of allelopathy. Past studies have often focused solely on extraction of plant material for evaluation of interesting secondary products that may or may not have ecological relevance. Today, we find that researchers are increasingly concerned with ecological and physiological relevance of these interactions and the mode of action of chemicals involved, despite their relative complexity. A new challenge that exists for plant scientists is to generate additional information on allelochemical mechanisms of release, selectivity and persistence in the rhizosphere, mode of action and genetic regulation. In this manner, we can further protect plant biodiversity and enhance weed management strategies in a variety of ecosystems.

\section{Literature cited}

Bais, H.P., T.S. Walker, F.R. Stermitz, R.A. Hufbauer, and J.M. Vivanco. 2002. Entaniomeric-dependent phytotoxic and antimicrobial activity of $(+-)$ catechin. A rhizosecreted racemic mixture from spotted knapweed. Plant Physiol. 128:11731179.

Bais, H.P., T.S. Walker, A.J. Kennan, F.R. Stermitz, and J.M. Vivanco. 2003a. Structure-dependant phytotoxicity of catechins and other flavonoids: Flavonoid conversions by cell-free protein extracts of Centaurea maculosa roots. J. Agr. Food Chem. 51:897-901.

Bais, H.P., R. Vepachedu, S. Gilroy, R.M. Callaway, and J.M. Vivanco. 2003b. Allelopathy and exotic plant invasion: From molecules and genes to species interactions. Science 301:1377-1380.

Barnes, J.P. and A.R. Putnam. 1983. Rye residues contribute weed suppression in no-tillage cropping systems. J. Chem. Ecol. 9:1045-1057.

Barnes, J.P. and A.R. Putnam. 1987. Role of benzoxazinones in allelopathy by rye (Secale cereale L.). J. Chem. Ecol. 13:889-905.

Barney, J.N. and A. DiTommasso. 2003. The biology of Canadian weeds. Artemisia vulgaris L. Can. J. Plant Sci. 83:205-215.

Barney, J.N., A.G. Hay, and L.A.Weston. 2005. Isolation and characterization of allelopathic volatiles from mugwort (Artemisia vulgaris). J. Chem. Ecol. (In press.)

Beerling, D.J., J.P. Bailey, and A.P. Conolly. 1994. Fallopia japonica (Houtt.) Ronse Decraene. Biological flora of the British Isles. J. Ecol. 82:959-979.

Bell, D.T. and C.H. Muller. 1973. Dominance of California annual grasslands by Brassica nigra. Amer. Midland Naturalist 90:277-299.

Bertholdsson, N-O. 2004. Variation in allelopathic activity over 100 years of barley selection and breeding. Weed Res. $44: 78-86$.

Bertin, C., R.N. Paul, S.O. Duke, and L.A. Weston. 2003. Laboratory assessment of the allelopathic potential of fine leaf fescues (Festuca rubra L.). J. Chem. Ecol. 8:1919-1937.

Blum, U. 1995. The value of model plant-microbe-soil system for understanding processes associated with allelopathic interactions, p. 127-131. In: Inderjit, K.M.M. Dakshini, and F.A. Einhellig (eds.). Allelopathy, organisms, processes and applications. Amer. Chem. Soc. Symp. Ser. 582. Washington D.C.

Blum, U. 1998. Effects of microbial utilization of phenolic acids and their phenolic acid breakdown products on allelopathic interactions. J. Chem. Ecol. 24:685-708.

Blum, U. 2002. Soil solution concentrations of phenolic acids as influenced by evapotranspiration. Third World Congr. Allelopathy. Abstr. No. 56.

Blum, U. and S.R. Shafer. 1988. Microbial populations and phenolic acids in soil. Soil Biol. Biochem. 20:793-800.

Burgos, N.R. and R.E. Talbert. 2000. Differential activity of allelochemicals from Secale cereale in seedling bioassays. Weed
Sci. 48:302-310.

Burgos, N.R., R.E. Talbert, and J.D. Mattice. 1999. Cultivar and age differences in the production of allelochemicals by Secale cereale. Weed Sci. 47:481-485.

Callaway, R.M. and E.T. Aschehoug. 2000. Invasive plants versus their new and old neighbors: A mechanism for exotic invasion. Science 290:521-523.

Chevallier, A. 1996. The encyclopedia of medicinal plants: A practical reference guide to more than 500 key medicinal plants and their uses. DK Publ., New York.

Chou, C.H. and H.J. Lin. 1976. Autointoxication mechanism of Oryza sativa. I. Phytotoxic effects of decomposing rice residues in soil. J. Chem. Ecol. 2:353-367.

Czarnota, M.A. Sorghum (Sorghum spp.) root exudates: Production, localization, chemical composition, and mode of action. PhD Diss., Cornell Univ., Ithaca, N.Y.

deCandolle, M.A.P. 1832. Physiologie Vegetale Bechet Jeune Lib. Facultie Medecine Paris 3:1474-1475.

Dilday, R.H., P. Nastasi, and R.J.J. Smith. 1991. Allelopathic activity in rice (Oryza sativa L.) against ducksalad (Heteranthera limosa), p. 193-201. In: M.J. Hanson, D.A. Ball, and C.V. Cole (eds.). Sustainable agriculture for the Great Plains, Symp. Proc. U.S.Dept. Agr., Washington, D.C.

Duke, S.O. 1986. Naturally occurring chemical compounds as herbicides. Rev. Weed Sci. 2:15-44.

Duke, S.O., F.E. Dayan, A.M. Rimando, K. Shrader, G. Aliotta, A. Oliva, and J.G. Romagni. 2002. Chemicals from nature for weed management. Weed Sci. 50:138-151.

Duke, S.O., F.E. Dayan, and J. Romagni. 2000. Natural products as sources for new mechanisms of herbicidal action. Crop Protection 19:583-589.

Duke, S.O., B.E. Scheffler, F.E. Dayan, L.A. Weston, and E. Ota. 2001. Strategies for using transgenes to produce allelopathic crops. Weed Technol. 15:826-834.

Einhellig, F.A. and J.A. Rasmussen. 1989. Prior cropping with grain-sorghum inhibits weeds. J. Chem. Ecol. 15:951-960.

Fortuna, A.M., E.C. de Riscala, C.A.N Catalan, T.E. Gedris, and W. Herz. 2002. Sesquiterpene lactones and other constituents of Centaurea diffusa. Biochem. Systems Ecol. 30:805-808.

Gonzalez, V.M., J. Kazimir, C. Nimbal, L.A. Weston, and G.M. Cheniae. 1997. Inhibition of a photosystem II electron transfer reaction by the natural product sorgoleone. J. Agr. Food Chem. 45:1415-1421. 
Hejl, A.M., F.A. Einhellig, and J.A. Rasmussen. 1993. Effects of juglone on growth, photosynthesis, and respiration. J. Chem. Ecol. 19:559-568.

Inderjit and L.A. Weston. 2000. Are laboratory bioassays suitable for prediction of field responses? J. Chem. Ecol. 26:2111-2118.

Inderjit and J. Weiner. 2001. Plant allelochemical interference or soil chemical ecology? Perspectives Plant Ecol. 4:3-12.

Inderjit and L.A. Weston. 2003. Root exudation: An overview, p. 235-255. In: H. deKroon (ed.). Root ecology. SpringerVerlag, London.

Kato-Noguchi, H., T. Ino, and N. Sata. 2002. Isolation and identification of a potent allelopathic substance in rice root exudates. Physiol. Plant. 115:401-405.

Kilronomos, J.N. 2002. Feedback with soil biota contributes to plant rarity and invasiveness in communities. Nature 417:67-70.

Kimura, Y., M. Kozawa, K. Baba, and K. Hata. 1983. New constituents of roots of Polygonum cuspidatum. J. Medicinal Plant Res. 48:164-168.

Macias, F.A. 2002. New approaches in allelopathy, challenge for the new millenium. Third World Congr. Allelopathy. Abstr. No. 38.

Masiunas, J.B., L.A. Weston, and S.C. Weller. 1995. The impact of rye cover crops on weed populations in a tomato cropping system. Weed Sci. 43:318-323.

Mattice, J., T. Lavy, B. Skulman, and R. Dilday. 1998. Searching for allelochemicals in rice that control ducksalad, p. 81-98. In: M. Olofsdotter (ed.). Allelopathy in rice: Proc. Wkshp. Allelopathy Rice. Intl. Rice Res. Inst., Manila, Phillipines.

Moyer, J.R., R.E. Blackshaw, E.G. Smith, and S. McGinn. 2000. Cereal cover crops for weed suppression in a summer fallowwheat cropping sequence. Can. J. Plant Sci. 80:441-449.

Muir, A.D. and W. Majak.1983. Allelopathic potential of diffuse knapweed (Centaurea diffusa) extracts. Can. J. Plant Sci. 63:989-996.

Muller, C.H. 1969. Allelopathy as a factor in ecological process. Vegetation 18:348-357.

Mwaja, V.N., J.B. Masiunas, and L.A. Weston. 1995. Effects of fertility on biomass, phytotoxicity, and allelochemical content of cereal rye. J. Chem. Ecol. $21: 81-96$.

Nagabhushana, G.G., A.D. Worsham, and J.P. Yenish. 2001. Allelopathic cover crops to reduce herbicide use in sustainable agricultural systems. Allelopathy J. 8:133-146.
Nair, M., C.J. Whitenack, and A.R. Putnam. 1990. 2,2'-Oxo-1,1'-azobenzene: A microbially transformed allelochemical from 2,3 benzoxazolinone. J. Chem. Ecol. $16: 353-364$.

Nimbal, C.I., J.F. Pedersen, C.N. Yerkes, S.C.Weller, and L.A.Weston. 1996a. Phytotoxicity and distribution of sorgoleone in grain sorghum germplasm. J. Agr. Food Chem. 44:1343-1347.

Nimbal, C.I., C.N. Yerkes, S.C. Weller, and L.A. Weston. 1996b. Herbicidal activity and site of action of the natural product sorgoleone. Pesticide Biochem. Physiol. $54: 73-83$

Olofsdotter, M., L.B. Jensen, and B. Courtois. 2002. Improving crop competitive ability using allelopathy-An example from rice. Plant Breeding 121:1-9.

Petersen, J., R. Belz, F. Walker, and K. Hurle. 2001. Weed suppression by release of isothiocyanates from turnip-rape mulch. Agron. J. 93:37-43.

Putnam, A.R. 1986. Can it be managed to benefit horticulture? HortScience 21:411-413.

Putnam, A.R. 1988. Allelochemicals from plants as herbicides. Weed Technol. 2:510-518.

Putnam, A.R. and W.O. Duke. 1974. Biological suppression of weeds: Evidence for allelopathy in accessions of cucumber. Science 185:370-372.

Putnam, A.R. and W.O. Duke. 1978. Allelopathy in agroecosystems. Ann. Rev. Phytopathol. 16:431-451.

Putnam, A.R. and L.A. Weston. 1986. Adverse impacts of allelopathy in agricultural systems, p. 43-56. In: A.R. Putnam and C.S. Tang (eds.). The science of allelopathy. Wiley, New York.

Qasem, J.R. and C.L. Foy. 2001. Weed allelopathy, its ecological impacts and future prospects: A review, p. 43-119. In: R.K. Kohli, H.P. Singh and D.R. Batish (eds.). Allelopathy in agroecosystems. Haworth Press, New York.

Rice, E.L. 1984. Allelopathy. Academic Press, Orlando, Fla.

Ridenour, W.M. and R.M. Callaway. 2001. The relative importance of allelopathy in interference: The effects of an invasive weed on a native bunchgrass. Oecologia 126:444-450

Rimando, A.M. and S.O. Duke. 2003. Studies on rice allelochemicals, p. 221-224. In: C.W. Smith (ed.). Rice: Origin, history, technology and production. Wiley, New York.

Scheffler, B.E., S.O. Duke, F.E. Dayan, and E. Ota. 2001. Crop allelopathy: Enhance- ment through biotechnology. Recent Adv. Phytochem. 35:257-274.

Sene, M., C. Gallet, and T. Dore. 2001. Phenolic compounds in a Sahelian sorghum (Sorghum bicolor) genotype [ce(145-66)] and associated soils. J. Chem. Ecol. 27:81-92.

Shilling, D.G., R.A. Liebl, and A.D.Worsham. 1985. Rye (Secale cereale L.) and wheat (Triticum aestivum L.) mulch: The suppression of certain broadleaved weeds and the isolation and identification of phytotoxins, p. 243-271. In: A.R. Putnam and C.S. Tang (eds.). The science of allelopathy. Wiley, New York.

Siemens, D.H., S.H. Garner, T. MitchellOlds, and R.M. Callaway. 2002. Cost of defense in the context of plant competition: Brassica rapa may grow and defend. Ecology 83:505-517.

Singh, H.P., D.R. Batish, and R.K. Kohli. 2001. Allelopathy in agroecosystems: An overview, p. 1-4l. In: R.K. Kohli, H.P. Singh, and D.R. Batish (eds.). Allelopathy in agroecosystems. Haworth Press, New York.

Vaughn, S.F. and M.A. Berhow. 1999. Allelochemicals isolated from tissues of the invasive weed garlic mustard (Alliara petiolata). J. Chem. Ecol. 25:2495-2504.

Weston, L.A. 1990. Cover crop and herbicide influence on row crop seedling establishment in no-tillage culture. Weed Sci. 38:166-171.

Weston, L.A. 1996. Utilization of allelopathy for weed management in agroecosystems. Agron. J. 88:860-866.

Weston, L.A. and S.O. Duke. 2003. Weed and crop allelopathy. Critical Rev. Plant Sci. 22:367-389.

Weston, L.A., R. Harmon, and S. Mueller. 1989. Allelopathic potential of sorghumsudangrass hybrid (sudex). J. Chem. Ecol. 15:1855-1865.

Willis, R.J. 1997. The history of allelopathy. 2. The second phase (1900-1920). The era of S.U. Pickering and the USDA Bureau of Soils. Allelopathy J. 4:7-56.

Willis, R.J. 2000. Juglansspp., juglone and allelopathy. Allelopathy J. 7:1-55.

Wink, M. 1999. Introduction: Biochemistry, role and biotechnology of secondary metabolites, p. 1-16. In: M. Wink (ed.). Functions of plant secondary metabolites and their exploitation in biotechnology. Annu. Plant Rev., Vol. 3. CRC Press, Boca Raton, Fla.

Yang, X., B. Scheffler, and L.A. Weston. 2004. Cloning of SOR 1, a gene associated with bioherbicide production in sorghum root hairs. J. Expt. Bot. 55:2251-2259. 